\title{
CORRECTION
}

\section{Correction to: Estimation of Low-Cycle Fatigue Lifetime in Aluminum-Silicon-Magnesium Alloy of Cylinder Heads based on Striation Marks as Failure Features of Fracture Surfaces and Paris Crack Growth Law}

Mohammad Azadi (1) - Mahdi Samiee $\cdot$ Sattar Mohammadi Esfarjani

Published online: 9 October 2021

(C) ASM International 2021

Correction to: J Fail. Anal. and Preven. (2021)

21:1466-1475

https://doi.org/10.1007/s11668-021-01196-6

The original online version of this article was revised: The column headings in Table 3 have been corrected.
Publisher's Note Springer Nature remains neutral with regard to jurisdictional claims in published maps and institutional affiliations.

The original article can be found online at https://doi.org/10.1007/ s11668-021-01196-6.

M. Azadi $(\varangle) \cdot$ M. Samiee $\cdot$ S. M. Esfarjani

Faculty of Mechanical Engineering, Semnan University,

Semnan, Iran

e-mail: m_azadi@semnan.ac.ir 